\title{
PEMODELAN MATEMATIS PENGURANGAN COD DALAM AIR LIMBAH INDUSTRI PENYAMAKAN KULIT SECARA ADSORPSI KONTINYU MENGGUNAKAN ABU TERBANG BAGAS
}

\section{MATHEMATICAL MODELLING FOR REDUCTION OF COD IN TANNERY WASTEWATER THROUGH CONTINUOUS ADSORPTION USING BAGASSE FLY ASH}

\author{
Agus Prasetya ${ }^{1)}$, Sarto $^{1)}$, Muhammad Sholeh ${ }^{2)}$ \\ ${ }^{1)}$ Jurusan Teknik Kimia Universitas Gadjah Mada, Yogyakarta \\ ${ }^{2)}$ Balai Besar Kulit, Karet, dan Plastik, Yogyakarta \\ Email: sholeh_tahunan@yahoo.com
}

Diterima: 10 Januari 2013 Direvisi: 20 Maret 2013 Disetujui: 23 April 2013

\begin{abstract}
The objective of this research was to obtain suitable mathematical model for Chemical Oxygen Demand (COD) removal originated from tannery wastewater using bagasse fly ash in continuous system. In the column experiment, effect of flowrate, concentration of wastewater, and bulk density were studied. Three models: Adams-Bohart, Thomas, and Yan were applied to experimental data to predict the breakthrough curve. The best model was evaluated using correlation coefficients. Yan model was found to give the most accurate to describe dynamic behavior of the column experiment. The best result was obtained at flowrate of $100 \mathrm{~mL} / \mathrm{min}$, concentration of $400 \mathrm{mg} / \mathrm{L}$, and bulk density of $61 \mathrm{~g} / \mathrm{L}$. The Yan kinetic constant $\left(k_{\gamma}\right)$ and the adsorption capacity $\left(q_{v}\right)$ were $0.3210 \mathrm{~mL} / \mathrm{mg} / \mathrm{min}$ and $17.0947 \mathrm{mg} / \mathrm{g}$ respectively and the correlation coefficient obtained was 0.9379 .
\end{abstract}

Keywords: Chemical Oxygen Demand, tannery wastewater, bagassefly ash, adsorption

\begin{abstract}
ABSTRAK
Penelitian ini bertujuan untuk mendapatkan model matematis yang sesuai untuk proses pengurangan COD dalam air limbah industri penyamakan kulit mengunakan abu terbang bagas secara kontinyu. Variasi percobaan adsorpsi dalam kolom yang dilakukan yaitu: kecepatan aliran air limbah, konsentrasi air limbah, dan bobot isi. Persamaan Adams-Bohart, Thomas, dan Yan diaplikasikan ke data percobaan untuk memprediksikan kurva breakthrough. Koefisien korelasi digunakan untuk mengevaluasi model terbaik. Proses pengurangan COD dengan abu terbang bagas secara kontinyu dalam kolom paling cocok dimodelkan dengan model Yan. Hasil terbaik diperoleh pada kecepatan aliran air limbah $100 \mathrm{~mL} / \mathrm{menit}$, konsentrasi air limbah $400 \mathrm{mg} / \mathrm{L}$, dan bobot isi $61 \mathrm{~g} / \mathrm{L}$. Parameter konstanta kinetika $\left(\mathrm{k}_{\mathrm{Y}}\right)$ dan kapasitas adsorpsi $\left(\mathrm{q}_{\mathrm{Y}}\right)$ yang diperoleh berturut-turut sebesar $0,3210 \mathrm{~mL} / \mathrm{mg} / \mathrm{menit}$ dan $17,0947 \mathrm{mg} / \mathrm{g}$ dengan nilai koefisien korelasi yang didapatkan yaitu 0,9379 .
\end{abstract}

Kata kunci: Chemical Oxygen Demand, air limbah industri penyamakan kulit, abu terbang bagas, adsorpsi 


\section{PENDAHULUAN}

Industri penyamakan kulit dikenal mengkonsumsi air dalam jumlah besar. Polusi yang ditimbulkan berasal dari berbagai bahan organik dan anorganik yang dipakai selama proses penyamakan, diantaranya bahan penyamak, garam, minyak, surfaktan, cat, fungisida, dan lain-lain. Karena keterbatasan proses pengolahan air limbah primer dan sekunder, alternatif lain proses telah diusulkan, diantaranya elektrokoagulasi (Sengil et al., 2009; Apaydin et al., 2009), wetland (Calheiros et al., 2009), membran (Stoller et al., 2013) dan adsorpsi (Yakubu et al., 2008).

Adsorpsi diketahui merupakan metode yang efisien untuk menghilangkan warna, bau, minyak, dan organik dari air limbah. Hal penting dalam proses ini adalah menggunakan adsorben yang murah namun efektif, diantaranya abu terbang bagas. Abu terbang bagas adalah limbah industri gula yang didapat dari hasil pembakaran bagas untuk boiler. Bahan ini kurang memiliki nilai tambah bagi pabrik gula dan hanya perlu ongkos pengangkutan apabila ingin memanfaatkannya. Beberapa penelitian pemanfaatan abu terbang bagas untuk mengurangi COD dari air limbah telah dilakukan, diantaranya air limbah penyulingan minuman beralkohol (Kulkarni, et al., 2011) dan air limbah industri gula (Lakdawala and Patel, 2012).

Desain adsorber fixed bed memerlukan data kesetimbangan adsorpsi, kinetika dan pemodelan matematis yang sesuai berdasarkan kurva breakthrough yang diperoleh dari percobaan skala laboratorium. Bentuk kurva breakthrough dalam kolom dipengaruhi antara lain oleh kecepatan aliran fluida, konsentrasi adsorbat dalam umpan, dan tinggi bed. Model matematis telah banyak dikembangkan untuk mendiskripsikan penjerapan polutan pada adsorber berbentuk kolom (Pokhrel and Viraraghavan, 2008; Ghomshe et al., 2011; Sekhula et al., 2012).

Penelitian ini bertujuan untuk mendapatkan bentuk model matematis yang sesuai untuk proses pengurangan COD dalam air limbah industri penyamakan kulit mengunakan abu terbang bagas secara kontinyu.

\section{BAHAN DAN METODE}

\section{Bahan Penelitian}

Abu terbang bagas diperoleh dari dust collector PT. Madubaru Yogyakarta. Air limbah industri penyamakan kulit diperoleh dari Laboratorium Penyamakan Kulit Balai Besar Kulit, Karet, dan Plastik. $\mathrm{H}_{2} \mathrm{SO}_{4}$ dan $\mathrm{H}_{2} \mathrm{O}_{2}$ analytical grade (Merck).

\section{Peralatan Penelitian}

Rangkaian alat kolom adsorpsi, terlihat pada Gambar 1, terdiri dari kolom adsorpsi dengan diameter $2,5 \mathrm{~cm}$ berisi abu terbang bagas dengan ketebalan $40 \mathrm{~cm}$ dan pecahan kaca, bak penampung air limbah, flowmeter dan keran.

\section{Metode Penelitian}

Air limbah dengan konsentrasi tertentu sebanyak 50 L dimasukkan ke dalam bak penampung lalu dialirkan secara gravitasi dengan kecepatan tertentu ke dalam kolom yang telah diisi dengan abu terbang bagas dengan bobot isi tertentu. Abu terbang bagas yang digunakan berukuran $-20+35$ mesh . Sebelum dan sesudah abu terbang bagas diberi pecahan kaca untuk menghomogenkan aliran limbah. Setiap beberapa menit diambil sampel sebanyak $5 \mathrm{~mL}$ lalu diukur kadar CODnya.

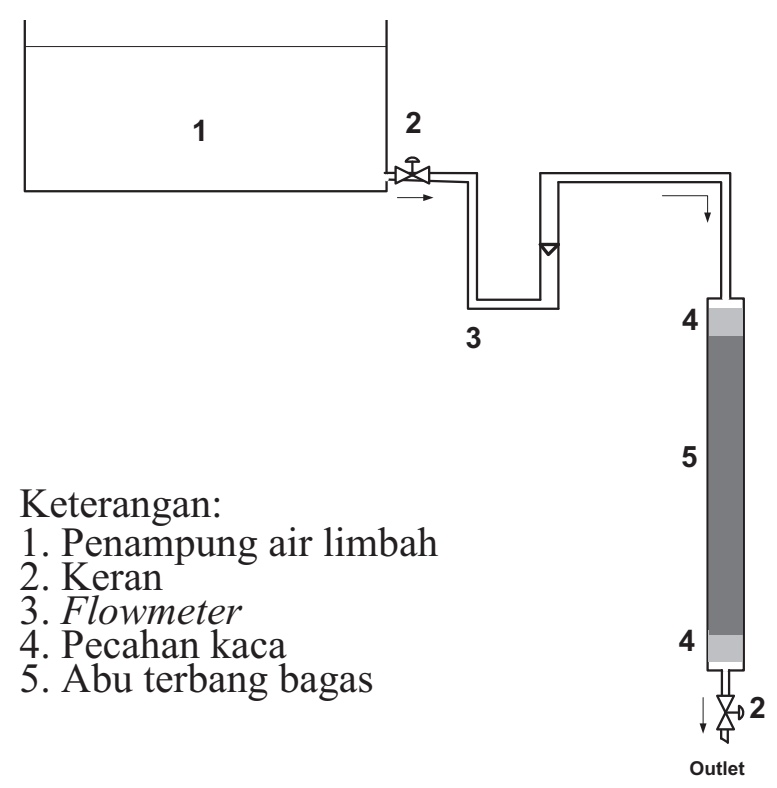

Gambar 1. Rangkaian alat adsorpsi secara kontinyu dalam kolom 
Aliran dihentikan bila kolom telah jenuh. Variasi yang dilakukan yaitu kecepatan aliran air limbah 20, 50, dan $100 \mathrm{~mL} /$ menit, konsentrasi air limbah 200 dan $400 \mathrm{mg} / \mathrm{L}$, dan bobot isi $61 \mathrm{dan} 89 \mathrm{~g} / \mathrm{L}$.

Kadar COD air limbah diukur sesuai SNI 6989.73:2009 Air dan air limbah - bagian 73: Cara uji kebutuhan oksigen kimiawi (Chemical Oxygen Demand/COD) dengan refluks tertutup secara titrimetri (BSN, 2009).

Data dievaluasi menggunakan tiga model, yaitu Adams-Bohart, Thomas, dan Yan. Model Adams-Bohart dituliskan dalam bentuk linier sebagai berikut (Ghomshe et al., 2011):

$$
\ln \frac{\mathrm{C}}{\mathrm{C}_{\mathrm{o}}}=\mathrm{k}_{\mathrm{AB}} \mathrm{C}_{\mathrm{o}} \mathrm{t}-\mathrm{k}_{\mathrm{AB}} \mathrm{q}_{\mathrm{AB}} \frac{\mathrm{z}}{\mathrm{U}}
$$

dimana $\mathrm{C}$ adalah konsentrasi COD limbah setelah melewati kolom adsorpsi, mg/L, $\mathrm{C}_{\text {o }}$ adalah konsentrasi COD limbah sebelum adsorpsi, $\mathrm{mg} / \mathrm{L}, \mathrm{k}_{\mathrm{AB}}$ adalah konstanta kinetika pada model Adams-Bohart, $\mathrm{mL} / \mathrm{mg} /$ menit, $\mathrm{t}$ adalah waktu pengaliran, menit, $\mathrm{q}_{\mathrm{AB}}$ adalah kapasitas adsorpsi pada model Adams-Bohart, $\mathrm{mg} / \mathrm{L}, \mathrm{z}$ adalah posisi arah aksial dalam kolom, $\mathrm{cm}$, dan $\mathrm{U}$ adalah kecepatan aliran limbah melewati kolom, cm/menit.

Model Thomas dituliskan sebagai berikut(Sekhula et al., 2012)

$$
\ln \left(\frac{\mathrm{C}_{\mathrm{o}}}{\mathrm{C}}-1\right)=\frac{\mathrm{k}_{\mathrm{Th}}}{\mathrm{Q}} \mathrm{q}_{\mathrm{Th}} \mathrm{W}-\mathrm{k}_{\mathrm{Th}} \mathrm{C}_{\mathrm{o}} \mathrm{t}
$$

dimana $\mathrm{k}_{\mathrm{Th}}$ adalah konstanta kinetika pada model Thomas, $\mathrm{mL} / \mathrm{mg} / \mathrm{menit}$, $\mathrm{Q}$ adalah debit cairan melewati kolom, mL/menit, $\mathrm{q}_{\mathrm{Th}}$ adalah kapasitas adsorpsi pada model Thomas, mg/g, dan W adalah massa abu terbang bagas, $\mathrm{g}$.

Yan et al. (2001) dalam Pokhrel and Viraraghavan (2008) mengusulkan suatu persamaan empiris yang bisa mengatasi kelemahan Model Thomas khususnya dalam memprediksi konsentrasi limbah pada waktu nol. Model Yan dituliskan sebagai berikut:

$$
\begin{aligned}
& \ln \left(\frac{\mathrm{C}}{\mathrm{C}_{0}-\mathrm{C}}\right)=\mathrm{a} \ln \mathrm{V}-\mathrm{a} \ln \mathrm{f} \\
& \mathrm{f}=\frac{\mathrm{k}_{\mathrm{Y}} \mathrm{q}_{\mathrm{Y}} \mathrm{W}}{\mathrm{Q}}
\end{aligned}
$$

$\mathrm{a}=\frac{\mathrm{k}_{\mathrm{Y}} \mathrm{C}_{0}}{\mathrm{Q}}$

dimana $\mathrm{V}$ adalah volume limbah, $\mathrm{mL}, \mathrm{k}_{\mathrm{Y}}$ adalah konstanta kinetika pada model Yan, $\mathrm{mL} / \mathrm{mg} / \mathrm{menit}$, dan $\mathrm{q}_{\mathrm{Y}}$ adalah kapasitas adsorpsi pada model Yan, mg/g.

\section{HASILDAN PEMBAHASAN}

\section{Pengaruh konsentrasi COD umpan}

Gambar 2 menunjukkan bahwa semakin kecil konsentrasi COD umpan memberikan kurva breakthrough yang semakin landai. Hal ini menunjukkan bahwa volume limbah yang dapat dilewatkan melalui kolom sampai terjadinya kondisi jenuh semakin besar dengan mengecilnya konsentrasi COD umpan. Konsentrasi COD umpan yang semakin besar mempercepat tercapainya kondisi jenuh dari abu terbang bagas. Hal ini karena semakin banyaknya permukaan tempat adsorpsi yang tertutupi oleh polutan (Han et al., 2009 dalam Nidheesh et al., 2013).

$\mathrm{C} / \mathrm{C}_{\mathrm{o}}$ naik secara tajam di awal kurva breakthrough sebelum $\mathrm{t} / \tau=1$. Hal ini menunjukkan bahwa pada percobaan ini difusi aksial cukup signifikan dan/atau terjadi channeling. Fenomena yang sama diperoleh oleh Pokhrel and Viraraghavan (2008). Terjadi perubahan gradien kurva breakthrough yang drastis pada $\mathrm{C} / \mathrm{C}_{\mathrm{o}}>0,4$ sehingga pada $\mathrm{t} / \tau=30$ adsorben belum mencapai kondisi jenuh. Hal ini disebabkan terjadi channeling dan/atau pada percobaan ini proses yang terjadi adalah adsorpsi multikomponen. Setiap senyawa memiliki kecepatan adsorpsi ke dalam abu

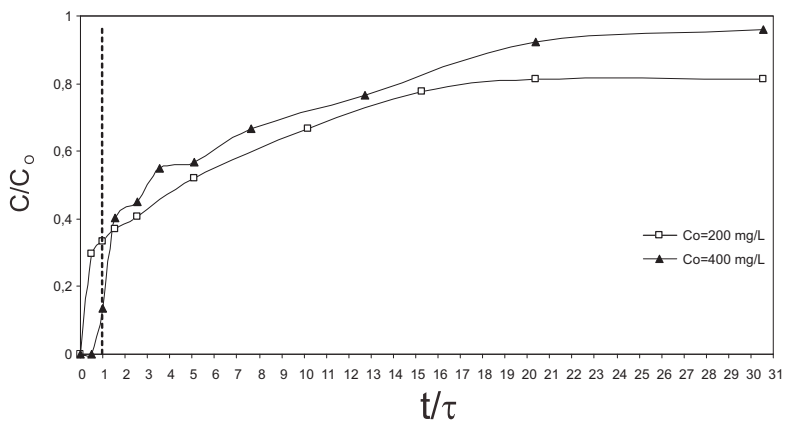

Gambar 2. Pengaruh konsentrasi COD umpan terhadap kurva breakthrough $(\mathrm{Q}=100$ $\mathrm{mL} / \mathrm{menit} ; \rho=$ bobot isi $=61 \mathrm{mg} / \mathrm{L} ; \tau=$ waktu tinggal cairan dalam kolom $=2,0$ menit) 


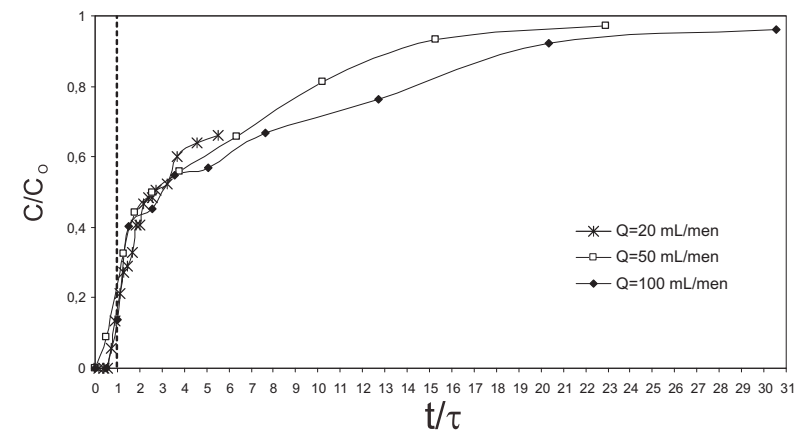

Gambar 3. Pengaruh kecepatan aliran limbah terhadap kurva breakthrough $\left(\mathrm{C}_{\mathrm{o}}=400\right.$ $\mathrm{mL} / \mathrm{men} ; \rho=61 \mathrm{mg} / \mathrm{L}$ )

terbang bagas yang berbeda, sehingga zona transfer massa yang terbentuk menjadi sangat lebar.

\section{Pengaruh kecepatan aliran air limbah}

Gambar 3 memperlihatkan bahwa semakin besar kecepatan aliran air limbah menghasilkan kurva breakthrough yang semakin landai. Peningkatan kecepatan aliran air limbah menghasilkan kapasitas kolom dalam mengurangi COD yang semakin besar.

\section{Pengaruh bobot isi abu terbang bagas}

Gambar 4 memperlihatkan bahwa bobot isi yang semakin besar memberikan kurva breakthrough yang semakin landai. Volume limbah yang dapat dilewatkan melalui kolom sampai terjadinya kondisi jenuh semakin besar dengan membesarnya bobot isi abu terbang bagas. Hal ini disebabkan massa abu terbang bagas dalam kolom pada bobot isi $89 \mathrm{mg} / \mathrm{L}$ lebih besar sehingga polutan yang terjerap bisa lebih banyak.

\section{Penentuan konstanta pada ketiga model matematis}

Model Adams-Bohart diaplikasikan untuk mendeskripsikan bagian awal dari kurva breakthrough. Data percobaan dalam kolom digunakan untuk menentukan konstanta dalam persamaan Adams-Bohart yaitu $\mathrm{k}_{\mathrm{AB}}$ dan $\mathrm{q}_{\mathrm{AB}}$ dengan membuat grafik hubungan antara $\mathrm{t}$ dengan $\ln \left(\mathrm{C} / \mathrm{C}_{\mathrm{o}}\right)$. Linierisasi dilakukan pada rentang nilai $\mathrm{C} / \mathrm{C}_{\mathrm{o}}$ di atas 0 dan di bawah 0,55 . Nilai $\mathrm{C} / \mathrm{C}_{\mathrm{o}}=0$ secara matematis tidak bisa digunakan untuk

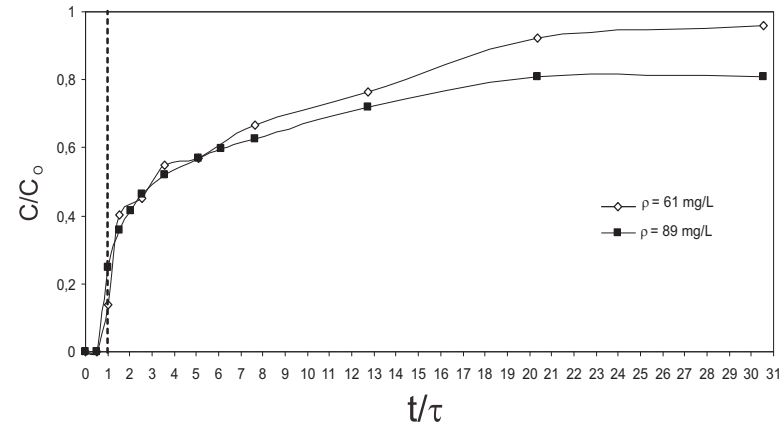

Gambar 4. Pengaruh bobot isi abu terbang bagas terhadap kurva breakthrough $(\mathrm{Q}=100$ $\mathrm{mL} / \mathrm{menit} \mathrm{C}_{\mathrm{o}}=400 \mathrm{mg} / \mathrm{L} ; \tau=2,0$ menit)

menghitung nilai $\ln \left(\mathrm{C} / \mathrm{C}_{\mathrm{o}}\right)$. Nilai di atas $\mathrm{C} / \mathrm{C}_{\mathrm{o}}$ $=0,55$ dilihat dari bentuk kurva breakthrough yang diperoleh tidak cocok dengan kurva model Adams-Bohart yang berbentuk eksponensial.

Konstanta kinetika Thomas $\left(\mathrm{k}_{\mathrm{TH}}\right)$ dan kapasitas maksimum kolom $\left(\mathrm{q}_{\mathrm{Th}}\right)$ dengan membuat hubungan antara $t$ dengan $\ln$ $\left(\mathrm{C}_{\mathrm{o}} / \mathrm{C}-1\right)$. Linierisasi dilakukan pada rentang nilai $\mathrm{C} / \mathrm{C}_{\mathrm{o}}$ di atas 0 dan di bawah 1 karena nilai $\mathrm{C} / \mathrm{C}_{\mathrm{o}}=0$ dan $\mathrm{C} / \mathrm{C}_{\mathrm{o}}=1$ secara matematis tidak bisa digunakan untuk menghitung nilai $\ln$ $\left(\mathrm{C}_{\mathrm{o}} / \mathrm{C}-1\right)$.

Konstanta kinetika Yan $\left(\mathrm{k}_{\mathrm{Y}}\right)$ dan kapasitas maksimum kolom $\left(\mathrm{q}_{\mathrm{Y}}\right)$ ditentukan dengan membuat hubungan antara $\ln \mathrm{V}$ dengan ln $\left(\mathrm{C} /\left(\mathrm{C}_{\mathrm{o}}-\mathrm{C}\right)\right)$. Linierisasi dilakukan pada rentang nilai $\mathrm{C} / \mathrm{C}_{\mathrm{o}}$ di atas 0 dan di bawah 1 karena nilai $\mathrm{C} / \mathrm{C}_{\mathrm{o}}=0$ dan $\mathrm{C} / \mathrm{C}_{\mathrm{o}}=1$ secara matematis tidak bisa digunakan untuk menghitung nilai $\ln \left(\mathrm{C} /\left(\mathrm{C}_{\mathrm{o}}-\mathrm{C}\right)\right)$.

Hasil perhitungan $\mathrm{k}_{\mathrm{AB}}$ dan $\mathrm{q}_{\mathrm{AB}}$ dari Persamaan (1), $\mathrm{k}_{\mathrm{TH}}$ dan $\mathrm{q}_{\mathrm{Th}}$ dari Persamaan (2), serta $\mathrm{k}_{\mathrm{Y}}$ dan $\mathrm{q}_{\mathrm{Y}}$ dari Persamaan (3) terangkum pada Tabel 1. Tabel 1 menunjukkan bahwa semakin tinggi konsentrasi umpan limbah cair mengakibatkan kapasitas maksimum kolom pada kondisi operasi tersebut $\left(\mathrm{q}_{\mathrm{AB}}, \mathrm{q}_{\mathrm{Th}}\right.$, dan $\left.\mathrm{q}_{\mathrm{Y}}\right)$ semakin tinggi. Menurut Aksu dan Gonen (2004), fenomena ini terjadi karena perbedaan konsentrasi yang tinggi memberikan driving force yang lebih besar sehingga kapasitas yang lebih tinggi dapat dicapai padakolom dengan konsentrasi umpan yang lebih tinggi. 
Tabel 1. Parameter model Adams-Bohart, Thomas, dan Yan pada berbagai variasi percobaan

Model Adams-Bohart

\begin{tabular}{rrrrrrl}
\hline $\begin{array}{l}\text { variasi } \\
\text { ke }\end{array}$ & $\begin{array}{l}\mathrm{C}_{\mathrm{o}} \\
(\mathrm{mg} / \mathrm{L})\end{array}$ & $\begin{array}{l}\mathrm{Q} \\
(\mathrm{mL} / \mathrm{men})\end{array}$ & $\begin{array}{l}\rho \\
(\mathrm{g} / \mathrm{L})\end{array}$ & $\begin{array}{l}\mathrm{k}_{\mathrm{AB}} \\
(\mathrm{mL} / \mathrm{mg} / \mathrm{men})\end{array}$ & $\begin{array}{l}\mathrm{q}_{\mathrm{AB}} \\
(\mathrm{mg} / \mathrm{g})\end{array}$ & $\mathrm{R}^{2}$ \\
\hline 1 & 400 & 100 & 61 & 0,273 & 41,68 & 0,6603 \\
2 & 200 & 100 & 61 & 0,346 & 32,04 & 0,9844 \\
3 & 400 & 50 & 61 & 0,312 & 28,04 & 0,6608 \\
4 & 400 & 20 & 61 & 0,168 & 22,60 & 0,7257 \\
5 & 400 & 100 & 89 & 0,351 & 24,72 & 0,8562 \\
\hline
\end{tabular}

Model Thomas

\begin{tabular}{rlrrrrl}
\hline $\begin{array}{l}\text { variasi } \\
\text { ke }\end{array}$ & $\begin{array}{l}\mathrm{C}_{\mathrm{o}} \\
(\mathrm{mg} / \mathrm{L})\end{array}$ & $\begin{array}{l}\mathrm{Q} \\
(\mathrm{mL} / \mathrm{men})\end{array}$ & $\begin{array}{l}\rho \\
(\mathrm{g} / \mathrm{L})\end{array}$ & $\begin{array}{l}\mathrm{k}_{\mathrm{Th}} \\
(\mathrm{mL} / \mathrm{mg} / \mathrm{men})\end{array}$ & $\begin{array}{l}\mathrm{q}_{\mathrm{Th}} \\
(\mathrm{mg} / \mathrm{g})\end{array}$ & $\mathrm{R}^{2}$ \\
\hline 1 & 400 & 100 & 61 & 0,1939 & 27,12 & 0,8777 \\
2 & 200 & 100 & 61 & 0,1705 & 25,61 & 0,8531 \\
3 & 400 & 50 & 61 & 0,1689 & 28,63 & 0,8414 \\
4 & 400 & 20 & 61 & 0,1340 & 23,24 & 0,7213 \\
5 & 400 & 100 & 89 & 0,1026 & 21,81 & 0,7934 \\
\hline
\end{tabular}

Model Yan

\begin{tabular}{rrrrrrl}
\hline $\begin{array}{l}\text { variasi } \\
\text { ke }\end{array}$ & $\begin{array}{l}\mathrm{C}_{\mathrm{o}} \\
(\mathrm{mg} / \mathrm{L})\end{array}$ & $\begin{array}{l}\mathrm{Q} \\
(\mathrm{mL} / \mathrm{men})\end{array}$ & $\begin{array}{l}\rho \\
(\mathrm{g} / \mathrm{L})\end{array}$ & $\begin{array}{l}\mathrm{k}_{\mathrm{Y}} \\
(\mathrm{mL} / \mathrm{mg} / \mathrm{men})\end{array}$ & $\begin{array}{l}\mathrm{q}_{\mathrm{Y}} \\
(\mathrm{mg} / \mathrm{g})\end{array}$ & $\mathrm{R}^{2}$ \\
\hline 1 & 400 & 100 & 61 & 0,3210 & 17,0947 & 0,9379 \\
2 & 200 & 100 & 61 & 0,3095 & 16,4547 & 0,9539 \\
3 & 400 & 50 & 61 & 0,1596 & 13,9749 & 0,9586 \\
4 & 400 & 20 & 61 & 0,0687 & 12,5143 & 0,9164 \\
5 & 400 & 100 & 89 & 0,1866 & 14,6137 & 0,9796 \\
\hline
\end{tabular}

Harga konstanta kinetika $\left(\mathrm{k}_{\mathrm{Th}}\right.$ dan $\left.\mathrm{k}_{\mathrm{Y}}\right)$ menunjukkan kecenderungan semakin tinggi pada konsentrasi awal yang semakin tinggi, namun konstanta kinetika Adams-Bohart $\left(\mathrm{k}_{\mathrm{AB}}\right)$ semakin rendah pada konsentrasi awal yang semakin tinggi. $\mathrm{k}_{\mathrm{AB}}$ mengalami kecenderungan yang terbalik dengan konstanta kinetika yang lain. Hal ini menunjukkan asumsi kecepatan adsorpsi yang didekati dengan kecepatan kinetika quasichemical pada model Adams-Bohart tidak dapat digunakan pada sistem ini. Terlihat pada Tabel 1 bahwa nilai koefisien korelasi yang diperoleh pada model Adams-Bohart tidak terlalu besar. Kecepatan aliran air limbah yang semakin tinggi menyebabkan kapasitas kolom semakin tinggi. Hal ini menunjukkan kecepatan yang semakin tinggi meningkatkan driving force proses adsorpsi. Harga konstanta kinetika $\left(\mathrm{k}_{\mathrm{Th}}\right.$, dan $\left.\mathrm{k}_{\mathrm{Y}}\right)$ juga meningkat seiring kenaikan kecepatan aliran cairan. Kenaikan harga konstanta kinetika Thomas dan Yan memperlihatkan bahwa tahanan transfer massa di lapisan cairan tidak dapat diabaikan pada kondisi operasi yang dilakukan. Konstanta kinetika Adams-Bohart yang diperoleh tidak memperlihatkan kecenderungan yang jelas. Model ini tampak tidak valid untuk sistem ini meskipun hanya untuk bagian awal dari kurva breakthrough. Bobot isi yang semakin besar mengakibatkan kapasitas maksimum kolom dan konstanta kinetika semakin rendah. Hal ini disebabkan karena pada bobot isi yang lebih besar, jarak antar butir abu terbang bagas semakin rapat dan permukaan luar butir yang saling bersinggungan semakin besar sehingga luas permukaan butir yang efektif berkontak dengan cairan menjadi semakin kecil.

Gambar 5 memperlihatkan kurva 


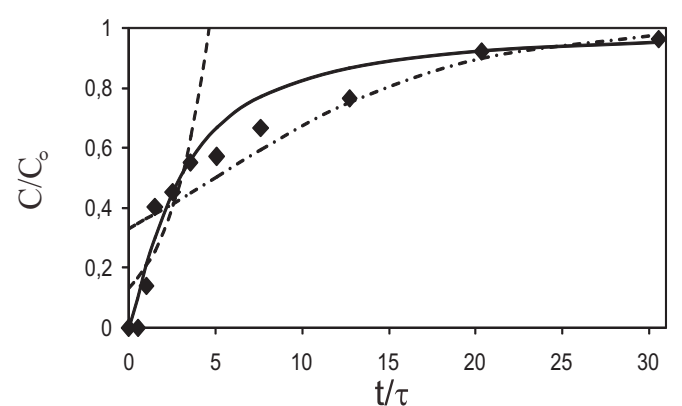

(a) $\rho=61 \mathrm{~g} / \mathrm{L} ; \mathrm{Q}=100 \mathrm{~mL} / \mathrm{menit} ; \mathrm{C}_{\mathrm{o}}=400 \mathrm{mg} / \mathrm{L}$

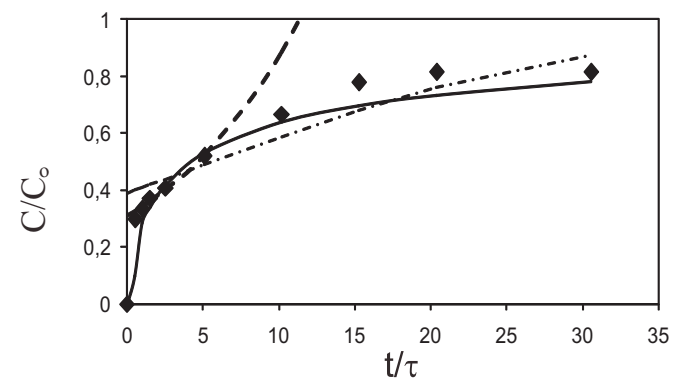

(b) $\rho=61 \mathrm{~g} / \mathrm{L} ; \mathrm{Q}=100 \mathrm{~mL} / \mathrm{menit} \mathrm{C}_{\mathrm{o}}=200 \mathrm{mg} / \mathrm{L}$

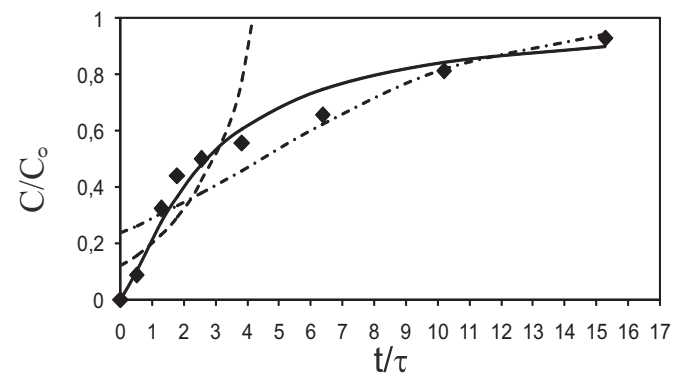

(c) $\rho=61 \mathrm{~g} / \mathrm{L} ; \mathrm{Q}=50 \mathrm{~mL} / \mathrm{menit} ; \mathrm{C}_{\mathrm{o}}=400 \mathrm{mg} / \mathrm{L}$

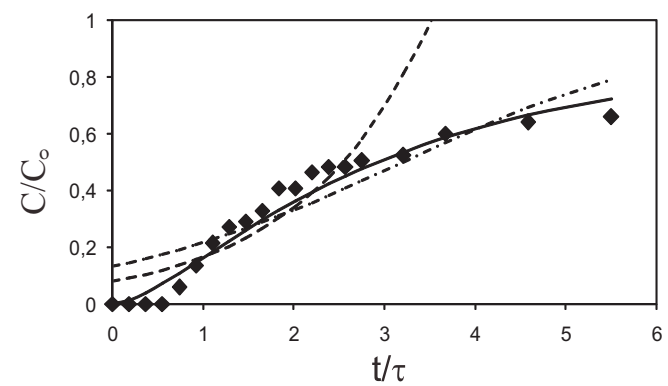

(d) $\rho=61 \mathrm{~g} / \mathrm{L} ; \mathrm{Q}=20 \mathrm{~mL} / \mathrm{menit} ; \mathrm{C}_{\mathrm{o}}=400 \mathrm{mg} / \mathrm{L}$

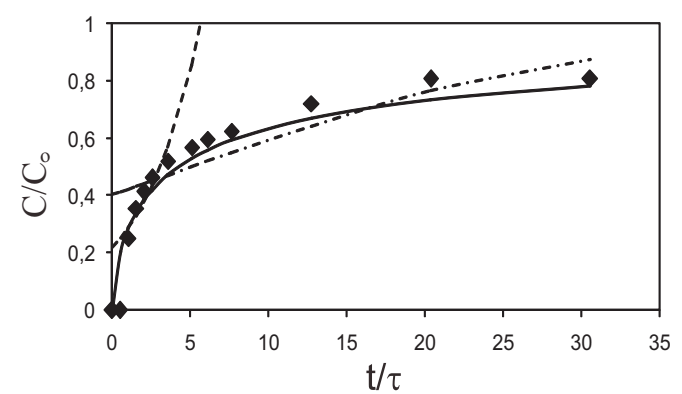

(e) $\rho=89 \mathrm{~g} / \mathrm{L} ; \mathrm{Q}=100 \mathrm{~mL} / \mathrm{menit} ; \mathrm{C}_{\mathrm{o}}=400 \mathrm{mg} / \mathrm{L}$

- - - Model Adams-Bohart $\quad$ - - - . M Model Thomas Model Yan $\quad$ Data percobaan

Gambar 5. Kurva breaktrough data eksperimen model Adams-Bohart, model Thomas, dan model Yan breakthrough tiap variasi percobaan yang diperoleh dari data eksperimen, model Adams-Bohart, model Thomas, dan model Yan. Perbandingan antara data percobaan dengan ketiga model menunjukkan bahwa hanya ada satu yang cocok pada keseluruhan rentang $\mathrm{C} / \mathrm{C}_{\mathrm{o}}$ yaitu model Yan. Model Thomas hanya bagus untuk daerah akhir kurva breakthrough $\left(\mathrm{C} / \mathrm{C}_{\mathrm{o}}>0,55\right)$. Model AdamsBohart tidak cukup baik untuk menggambarkan daerah awal kurva breakthrough. Daerah dimana $\mathrm{C} / \mathrm{C}_{\mathrm{o}}=0$ yaitu di awal waktu operasi kolom hanya dapat didekati dengan model Yan. Daerah akhir dapat didekati dengan model Thomas dan Yan.

Model Adams-Bohart berasumsi bahwa kecepatan adsorpsi dapat didekati dengan kecepatan kinetika quasi-chemical dan tidak ada dispersi aksial (Chu et al., 2010). Penyederhanaan tersebut tidak tepat untuk diaplikasikan pada percobaan ini. Hasil yang diperoleh menunjukkan bahwa sifat makroskopis dari abu terbang bagas seperti bobot isi mempengaruhi konstanta kinetika sehingga fase dalam kolom tidak dapat dianggap pseudo homogen. Bentuk kurva breakthrough memperlihatkan kemungkinan dispersi aksial cukup signifikan dan/atau terjadichanneling.

Model Thomas berasumsi proses adsorpsi mengikuti model Langmuir dan tidak ada dispersi aksial serta driving force mengikuti kinetika order dua (Aksu dan Gonen, 2004). Menurut Sholeh et al (2012) hasil percobaan secara batch menunjukkan bahwa adsorption isoterm untuk sistem ini lebih cocok digambarkan dengan model Freundlich. Model ini termasuk persamaan empiris yang paling awal digunakan untuk mendiskripsikan data kesetimbangan adsorpsi. Penurunan model Thomas yang berdasarkan kinetika reaksi order dua juga tidak tepat digunakan pada percobaan ini karena tahanan transfer massa di lapisan cairan terbukti tidak dapat diabaikan.

Model Yan merupakan persamaan empiris untuk memperbaiki model Thomas (Pokhrel dan Viraraghavan, 2008). Hasil perhitungan koefisien korelasi menunjukkan bahwa model Yan berhasil memperbaiki hasil buruk model Thomas dalam menggambarkan daerah awal kurva breakthrough. 


\section{KESIMPULAN}

Proses pengurangan COD dengan abu terbang bagas secara kontinyu dalam kolom paling cocok dimodelkan dengan model Yan. Pada semua variasi percobaan, nilai koefisien korelasi dari model Yan di atas 0,9. Model Thomas hanya bagus untuk daerah akhir kurva breakthrough $\left(\mathrm{C} / \mathrm{C}_{\mathrm{o}}>0,55\right)$. Model Adams-Bohart tidak cukup baik untuk menggambarkan daerah awal kurva breakthrough.

\section{UCAPAN TERIMA KASIH}

Penulis mengucapkan terima kasih kepada Balai Besar Kulit, Karet dan Plastik atas pemberian izin penggunaan fasilitas peralatan laboratorium selama pelaksanaan penelitian ini.

\section{DAFTAR PUSTAKA}

Aksu, Z. and Gonen, F., 2004. Biosorption of phenol by immobilized activated sludge in a continuous packed bed: prediction of breakthrough curve, Process Biochemistry, 39: 599-613.

Apaydin, O., Kurt, U. and Gonullu, M. T., 2009. An investigation on the treatment of tannery wastewater by electrocoagulation, Global NEST Journal, 11(4): 546-555.

BSN (Badan Standardisasi Nasional), 2009. SNI 6989.73:2009 Air dan air limbahbagian 73: cara uji kebutuhan oksigen kimiawi (chemical oxygen demand/ COD) dengan refluks tertutup secara titrimetri.

Calheiros, C. S. C., Rangel, A. O. S. S. and Castro, P. M. L, 2009. Treatment of industrial wastewater with two-stage constructed wetlands planted with Typha latifolia and Phragmites australis, Bioresource Technology, 100: 3205-3213.

Chu, K. H., Feng, X., Kim, E.Y. and Hung, Y., 2011. Biosorption Parameter Estimation with Genetic Algorithm, Water, 3:177195.

Ghomshe, S. M., Mousavi, S. M., Soltanieh, M. and Kordi, A. K. S., 2011. Batch and column study of haloacetic acids adsorption onto granular activated carbon, Scientific Research and Essays,6(16): 3553-3560.

Kulkarni, S. J., Patil, S. V. and Bhalerao, Y. P., 2011. Flyash adsorption studies for organic matter removal accompanying increase in dissolved oxygen, International Journal of Chemical Engineering and Applications, 2(6): 434-438.

Lakdawala, M. M. and Patel, Y. S., 2012, The effect of low cost material bagasse fly ash to the removal of COD Contributing component of combined waste water of sugar industry, Archives of Applied Science Research, 4(2): 852-857

Nidheesh, P. V., Gandhimathi, R., Ramesh, S. T. and Singh, T. S. A., 2013. Adsorption and desorption characteristics of crystal violet in bottom ash column, Journal of Urban and Environmental Engineering, 6(1): 18-29.

Pokhrel, D. and Viraraghavan, T., 2008. Arsenic removal in an iron oxide-coated fungal biomass column: analysis of breakthrough curves, Bioresource Technology, 99: 2067-2071.

Sekhula, M. M., Okonkwo, J. O., Zvinowanda, C. M., Agyei, N. N. and Chaudhary, A. J., 2012. Fixed bed column adsorption of $\mathrm{Cu}$ (II) onto maize tassel-PVA beads, Journal of Chemical Engineering and Process Technology, $3(2): 1-5$.

Sengil, I. A., Kulac, S. and Ozacar, M., 2009. Treatment of tannery liming drum wastewater by electrocoagulation, Journal of Hazardous Material, 176: 940-946.

Sholeh, M., Prasetya, A. dan Sarto, 2012, Pengolahan air limbah industri penyamakan kulit menggunakan abu terbang bagas secara batch, Majalah Kulit, Karet dan Plastik, 28(1): 25-33.

Stoller, M., Sacco O., Sannino, D. and Chianese, A.,2013. Successful integration of membrane technologies in a conventional purification process of tannery wastewater streams, Membranes, 3: 126-135.

Yakubu, M. K., Gumel, M. S. and Abdullahi, A. M., 2008. Use of activated carbon 
from date seeds to treat textile and tannery effluents, African Journal of Science and Technology, 9(1): 39-49. 